\title{
PENGIMBASAN KETAHANAN TANAMAN PISANG TERHADAP PENYAKIT DARAH (RALSTONIA SOLANACEARUM PHYLOTIPE IV) MENGGUNAKAN BAKTERI ENDOFIT
}

\author{
Husda Marwan \\ Program Studi Hama dan Penyakit Tumbuhan, Fakultas Pertanian Universitas Jambi \\ Kampus Pinang Masak Jl. Jambi-Muara Bulian, Jambi 36361 \\ E-mail : husdamarwan@yahoo.co.id
}

\begin{abstract}
Induced resistance of banana against blood disease (Ralstonia solanacearum Phylotipe IV) using endophytic bacteria. Endophytic bacteria play a role to control plant pathogenic bacteria indirectly by inducing the plant to increase production of the metabolites in activating the plant resistance. This study aimed to determine the ability of endophytic bacteria to induce resistance in banana plants against blood disease. Indicators of induced resistance of banana plant were analyzed through the existence of defense enzyme activities (peroxidase and polyphenol oxidase) and the amount of salicylic acid on banana roots. The results showed that endophytic bacteria isolates EAL15, EKK10, EKK20 and EKK22 suppressed the incidence of blood disease in Cavendish banana by 70-85\%. Increased activity of peroxidase and polyphenol oxidase in roots of banana plants were higher in plants treated with endophytic bacteria compared to untreated plants. Salicylic acid content in banana plants treated with isolates EAL15, EKK10 and EKK20 was higher than that of EKK22 isolates and control plants.
\end{abstract}

Key words: endophytic bacterium, induced resistance, peroxidase, polyphenol oxidase, salicylic acid

\section{ABSTRAK}

Pengimbasan ketahanan tanaman pisang terhadap penyakit darah (Ralstonia solanacearum Phylotipe IV) menggunakan bakteri endofit. Bakteri endofit dapat mengendalikan bakteri patogen tanaman secara tidak langsung dengan cara mengimbas tanaman untuk meningkatkan produksi senyawa metabolit yang berperan dalam mengaktifkan ketahanan tanaman. Penelitian ini bertujuan untuk mengetahui kemampuan bakteri endofit dalam mengimbas ketahanan tanaman pisang terhadap penyakit darah. Indikator pengimbasan ketahanan tanaman pisang dianalisis melalui aktivitas enzim pertahanan (peroksidase dan polifenol oksidase) dan kandungan asam salisilat pada akar tanaman pisang. Hasil penelitian menunjukkan bahwa isolat bakteri endofit EAL15, EKK10, EKK20 dan EKK22 mampu menekan kejadian penyakit darah pada pisang Cavendish sebesar 70-85\%. Peningkatan aktivitas peroksidase dan polifenol oksidase pada akar tanaman pisang lebih tinggi pada tanaman yang diperlakukan dengan bakteri endofit dibandingkan dengan tanaman tanpa perlakuan bakteri endofit. Selain itu, kandungan asam salisilat pada tanaman pisang yang diperlakukan dengan isolat EAL15, EKK10 dan EKK20 lebih tinggi dibandingkan dengan isolat EKK22 dan tanaman kontrol.

Kata kunci: asam salisilat, bakteri endofit, pengimbasan ketahanan, peroksidase, polifenol oksidase

\section{PENDAHULUAN}

Tanaman mampu bertahan terhadap serangan patogen melalui suatu kombinasi karakteristik struktural yang berperan dalam menghalangi masuknya patogen ke dalam jaringan tanaman dan reaksi biokimia di dalam sel atau jaringan yang menghalangi pertumbuhan patogen di dalam sel atau jaringan tanaman. Respon pertahanan biokimia tanaman terhadap serangan patogen meliputi pelepasan senyawa oksidatif yang dapat memicu terjadinya kematian sel (Lamb \& Dixon, 1997) sehingga patogen tidak dapat menyebar ke jaringan lain dari tanaman. Respon selanjutnya dari tanaman terjadi di sekeliling sel yaitu perubahan komposisi dinding sel yang dapat menghambat penetrasi dari patogen, mensintesis senyawa anti mikroba seperti fitoaleksin (Kuc,1995; Hammerschmidt, 1999), dan pathogenesis relatedprotein (van Loon, 1997).

Ketahanan tanaman dapat diimbas menggunakan agens pengimbas berupa stimulus biotik spesifik atau kimia (Kuc, 1987). Aplikasi agens pengimbas ketahanan tanaman menyebabkan peningkatan aktivitas dan kandungan senyawa-senyawa yang berhubungan dengan ketahanan tanaman seperti peroksidase, kitinase, $\beta-1,3$ glukanase, $\beta$-1,4 glukosidase, dan asam salisilat (Wei et al., 1996). Pengimbasan ketahanan 
dapat bersifat sistemik, karena peningkatan kapasitas pertahanan tidak hanya terjadi pada bagian tanaman yang diimbas, tetapi juga pada bagian lain dari tanaman yang tidak diimbas dan menyebar secara spasial pada jaringan tanaman (van Loon et al., 1998).

Aplikasi bakteri sebagai agens pengimbas ketahanan tanaman dapat dilakukan dengan menyiramkan bakteri atau campuran bakteri ke tanah steril, mencelupkan akar bibit tanaman ke dalam suspensi bakteri, melapisi (coating) benih dengan suspensi bakteri sebelum disemaikan (Kloepper \& Tuzun, 1996) dan selanjutnya tanaman diinfeksi dengan patogen. Pengimbasan ketahanan pada tanaman dapat diamati melalui indikator-indikator terjadinya proses pengimbasan tersebut, seperti aktivitas enzim-enzim yang berhubungan dengan ketahanan tanaman dan senyawa-senyawa yang dapat berperan sebagai elicitor pengimbas ketahanan tanaman.

Berdasarkan hasil penelitian Marwan et al. (2011), sebanyak 26 isolat bakteri endofit yang diisolasi dari akar beberapa jenis tanaman pisang mampu menekan kejadian penyakit darah pada pisang Cavendish sebesar 16,67-83,33\%. Isolat EAL15, EKK10, EKK20 dan EKK22 menunjukkan persentase penekanan kejadian penyakit lebih tinggi dibandingkan isolat lainnya yaitu sebesar $66,67-83,33 \%$. Penelitian ini bertujuan untuk menganalisis mekanisme pengimbasan ketahanan sistemik bakteri endofit dalam mengendalikan penyakit darah yang disebabkan oleh bakteri Ralstonia solanacearum Phylotipe IV pada tanaman pisang. Indikator terjadinya pengimbasan ketahanan pisang oleh bakteri endofit diamati melalui aktivitas enzim pertahanan tanaman (peroksidase dan polifenol oksidase) dan asam salisilat pada tanaman.

\section{METODE PENELITIAN}

Tempat dan Waktu. Penelitian dilakukan di Laboratorium Bakteriologi Tumbuhan Departemen Proteksi Tanaman IPB, Rumah Kaca Balai Besar Bioteknologi dan Sumberdaya Genetika, Laboratorium Bioproses PAU IPB, serta Laboratorium Pengujian Balai Besar Penelitian dan Pengembangan Pasca Panen Pertanian Bogor. Penelitian berlangsung mulai bulan Juni 2010 sampai dengan Maret 2011.

Persiapan Tanaman dan Aplikasi Bakteri Endofit. Percobaan ini menggunakan Rancangan Acak Lengkap dengan 5 ulangan, setiap ulangan terdiri atas 4 bibit pisang. Isolat bakteri endofit yang digunakan adalah EAL15, EKK10, EKK20 dan EKK22 yang menunjukkan kemampuan menekan kejadian penyakit darah (Marwan et al. 2011). Isolat EAL15 diisolasi dari akar tanaman pisang Ambon Lumut, sedangkan isolat EKK10, EKK20, dan EKK22 diisolasi dari akar tanaman pisang Kepok Kuning. Bibit pisang yang digunakan adalah pisang Cavendish hasil perbanyakan kultur jaringan dari BIOTROP Bogor.

Bibit pisang berumur 1 bulan dibersihkan dari kotoran media pembibitan dengan air mengalir, kemudian dikeringanginkan. Sebanyak 20 bibit untuk masingmasing perlakuan direndam dalam $1000 \mathrm{ml}$ suspensi bakteri endofit (populasi $10^{8}-10^{9} \mathrm{cfu} / \mathrm{ml}$ ) selama 6 jam, kemudian ditanam dalam pot plastik ukuran $20 \mathrm{~cm}$ yang berisi media tanah humus steril dan sekam bakar. Setelah masa kolonisasi bakteri endofit selama 8 minggu, tanaman pisang diinokulasi dengan bakteri patogen $R$. solanacearum Phylotipe IV.

Isolasi dan Inokulasi Bakteri Patogen Ralstonia solanacearum Phylotipe IV. Isolat bakteri patogen $R$. solanacearum Phylotipe IV diisolasi dari tandan buah tanaman pisang Kepok yang menunjukkan gejala penyakit darah. Tandan pisang yang terinfeksi patogen dipotong dengan ukuran $3 \times 3 \mathrm{~cm}$, kemudian direndam dalam Natrium hipoklorit $5 \%$ selama 1 menit dan dicuci sebanyak 4 kali dengan akuades steril. Potongan tandan ini diletakkan di dalam cawan Petri yang dialasi dengan kertas saring steril yang lembab sehingga lendir (ooze) bakteri berwarna putih kusam keluar dari potongan tersebut. Lendir bakteri ini kemudian diambil dengan jarum ose steril dan digoreskan pada media Sucrose Peptone Agar (komposisi: 20 g sukrosa; 5 g pepton; 0,5 g K2HPO4; 0,25 $\mathrm{g} \mathrm{MgSO}_{4} \cdot 7 \mathrm{H}_{2} \mathrm{O} ; 15 \mathrm{~g}$ agar; 1000 $\mathrm{ml}$ akuades) yang mengandung antibiotik Polymixin $b$ sulfat 1\% dan 2,3,5 Triphenyl Tetrazolium Chloride $1 \%$ (Lelliott \& Stead, 1987) dan diinkubasi selama 3 hari. Koloni bakteri yang menunjukkan karakter marfologi dari $R$. solanacearum Phylotipe IV dimurnikan dan dilakukan uji reaksi hipersensitif pada daun tembakau, serta uji patogenesitas pada bibit pisang Kepok.

Isolat murni bakteri $R$. solanacearum Phylotipe IV dibiakkan pada media Sucrose Peptone Agar selama 76 jam, kemudian disuspensikan dalam $10 \mathrm{ml}$ akuades steril dan dihitung populasinya menggunakan spektrofotometer sehingga mencapai $10^{8}-10^{9} \mathrm{cfu} / \mathrm{ml}$ $\left(\mathrm{OD}_{600}=0,16\right)$. Inokulasi $R$. solanacearum Phylotipe IV dilakukan dengan cara menyiramkan $25 \mathrm{ml}$ suspensi bakteri pada tanah sekitar perakaran tanaman pisang Cavendish yang telah dilukai dengan jarum steril. 
Pengamatan dilakukan terhadap periode inkubasi penyakit darah, persentase kejadian penyakit darah, aktivitas enzim pertahanan (peroksidase dan polifenol oksidase) dan kandungan asam salisilat. Persentase kejadian penyakit dihitung menggunakan rumus Agrios (2005) yaitu :

$$
\mathrm{KjP}=\frac{\mathrm{a}}{\mathrm{b}} \times 100 \%
$$

$\mathrm{KjP}=$ Kejadian penyakit $(\%)$

$\mathrm{a}=$ Jumlah tanaman yang menunjukkan gejala penyakit pada satu perlakuan

$\mathrm{b}=$ Jumlah tanaman pada perlakuan yang sama

Data hasil pengamatan periode inkubasi penyakit dan kejadian penyakit darah dianalisis secara statistik (ANOVA) dan perlakuan yang berpengaruh nyata dilakukan uji jarak berganda Duncan pada taraf $5 \%$.

Analisis Peroksidase (POD) dan Polifenol Oksidase (PPO). Analisis POD dan PPO dilakukan pada sampel akar tanaman pisang satu jam sebelum inokulasi bakteri patogen $R$. solanacearum Phylotipe IV dan 14 hari setelah diinokulasi bakteri patogen dengan dua tanaman setiap perlakuan. Ekstraksi enzim menggunakan metode Kumar et al. (2008). Sebanyak $1 \mathrm{~g}$ akar digerus menggunakan mortar dan dihomogenkan dalam bufer fosfat $0,1 \mathrm{M}(\mathrm{pH} 6,5)$ dengan perbandingan 1 : 5. Hasil ekstraksi disentrifugasi selama 20 menit dengan kecepatan $10.000 \mathrm{rpm}$ pada suhu $4^{\circ} \mathrm{C}$, kemudian supernatan dipindahkan ke tabung eppendorf baru sebagai ekstrak enzim yang digunakan untuk analisis aktivitas enzim POD dan PPO.

Analisis aktivitas enzim POD dan PPO dilakukan dengan metode Kumar et al. (2008). Campuran reaksi untuk analisis POD terdiri dari $0,05 \mathrm{ml}$ guiacol $20 \mathrm{mM}$; $3 \mathrm{ml}$ bufer fosfat; $0,1 \mathrm{ml}$ ekstrak enzim dan $0,03 \mathrm{ml}$ of $\mathrm{H}_{2} \mathrm{O}_{2}$. Nilai perubahan absorbansi dari campuran reaksi diukur menggunakan spektrofotometer pada panjang gelombang $420 \mathrm{~nm}$ selama 2,5 menit dengan interval waktu pengamatan setiap 30 detik.

Analisis aktivitas PPO menggunakan campuran reaksi yang terdiri dari $1,5 \mathrm{ml}$ bufer fosfat $0,1 \mathrm{M}(\mathrm{pH}$ 6,5); 0,5 ml ekstrak enzim dan 0,5 ml katekol 0,01 N. Nilai perubahan absorbansi dari campuran reaksi diukur menggunakan spektrofotometer pada panjang gelombang $495 \mathrm{~nm}$ selama 3 menit dengan interval waktu pengamatan setiap 30 detik.

Analisis Kandungan Asam Salisilat. Analisis kandungan asam salisilat dilakukan pada akar tanaman pisang 14 hari setelah diinokulasi dengan BDB dengan gabungan 3 tanaman setiap perlakuan. Ekstraksi dan kuantifikasi asam salisilat dilakukan dengan metode Rasmussen et al. (1991) yang dimodifikasi. Sebanyak 5 akar tanaman pisang digerus, kemudian diekstrak dengan metanol. Kandungan asam salisilat dianalisis dengan High-Performance Liquid Chromatography (HPLC). Sebanyak $5 \mu$ l ekstrak metanol akar pisang diinjeksikan pada C18 column (4,6 ID x $250 \mathrm{~mm}$; Lichrospher 100 Rp 18, Alltech, Deerfield, IL), diekuilibrasi dengan 5\% (v/v) bufer acetonitrile $(50 \mathrm{~mm}$ bufer sodium acetat, $\mathrm{pH} 4,5$ ). Asam salisilat akan dielusi isocratically 15 menit setelah injeksi, dan dideteksi dengan fluorescens (eksitasi $290 \mathrm{~nm}$; emisi $402 \mathrm{~nm}$ ). Konsentrasi asam salisilat diukur menggunakan jarak linier dari standar kalibrasi yang mengandung $0-1,3 \mathrm{mg} /$ $50 \mathrm{ml}$ asam salisilat (Sigma-Aldrich, St. Louis). Konsentrasi asam salisilat dinyatakan dalam mikrogram per gram berat segar. Analisis asam salisilat dilakukan di Laboratorium Pengujian, Balai Besar Penelitian dan Pengembangan Pasca Panen Pertanian Bogor.

\section{HASIL DAN PEMBAHASAN}

\section{Pengaruh Bakteri Endofit terhadap Penyakit}

Darah. Hasil analisis ragam menunjukkan bahwa perlakuan isolat bakteri endofit EAL15, EKK10, EKK20 dan EKK22 berpengaruh nyata terhadap periode inkubasi dan kejadian penyakit darah pada tanaman pisang Cavendish. Isolat-isolat tersebut mampu menekan kejadian penyakit darah sebesar 70-85\% (Tabel 1), sesuai dengan hasil pengujian sebelumnya dimana isolatisolat tersebut mampu menekan kejadian penyakit darah sebesar 66,67-83,33\% (Marwan et al., 2011).

Beberapa peneliti telah melaporkan bahwa bakteri endofit mampu mengendalikan penyakit tanaman melalui mekanisme pengimbasan ketahanan sistemik. Wei et al. (1991) melaporkan bahwa Pseudomonas fluorescens strain 89B-61 mengimbas ketahanan sistemik terhadap penyakit antraknose pada tanaman mentimun melalui aplikasi pada benih. Serratia marcescens strain 90166 mampu mengimbas ketahanan sistemik tanaman mentimun terhadap berbagai macam penyakit (Press et al. 2001). Harish et al. (2008) juga melaporkan bahwa aplikasi bakteri endofit dan rizobakteria mampu menekan penyakit Banana Bunchy Top Virus sebesar 60\% melalui mekanisme pengimbasan ketahanan sistemik.

Pengimbasan ketahanan tanaman oleh bakteri endofit menyebabkan tanaman mengekspresikan sejumlah respon pertahanan. Karakteristik respon metabolik dari mekanisme pertahanan sistemik adalah pengimbasan aktivitas enzim pertahanan seperti peroksidase, polifenol oksidase, atau enzim yang 
Tabel 1. Pengaruh perlakuan bakteri endofit terhadap perkembangan penyakit darah pada tanaman pisang Cavendish dua minggu setelah inokulasi $R$. solanacearum Phylotipe IV

\begin{tabular}{lccc}
\hline Perlakuan & $\begin{array}{c}\text { Periode inkubasi } \\
\left.\text { penyakit }(\mathrm{hsi})^{\mathrm{a}}\right)\end{array}$ & $\begin{array}{c}\text { Kejadian penyakit } \\
\left.\text { darah }(\%)^{\mathrm{a}}\right)\end{array}$ & $\begin{array}{c}\text { Penekanan kejadian } \\
\text { penyakit }(\%)\end{array}$ \\
\hline EAL15 & $11,50 \mathrm{ab}$ & $15,0 \mathrm{a}$ & 85,0 \\
EKK10 & $11,60 \mathrm{ab}$ & $30,0 \mathrm{a}$ & 70,0 \\
EKK20 & $10,60 \mathrm{~b}$ & $20,0 \mathrm{a}$ & 80,0 \\
EKK22 & $12,70 \mathrm{a}$ & $30,0 \mathrm{a}$ & 70,0 \\
Kontrol R. solanacearum & $10,46 \mathrm{~b}$ & $100,0 \mathrm{~b}$ & \\
\hline
\end{tabular}

a) Angka yang diikuti huruf yang sama pada kolom yang sama menunjukkan tidak berbeda nyata berdasarkan uji Duncan pada taraf nyata $5 \%$, hsi $=$ hari setelah inokulasi.

berhubungan dengan biosintesis fitoaleksin yaitu fenil alanin amonia liase (van Loon et al., 1998).

Aktivitas Peroksidase dan Polifenol Oksidase pada Tanaman Pisang. Hasil analisis aktivitas peroksidase dan polifenol oksidase menunjukkan bahwa peningkatan aktivitas kedua enzim tersebut terjadi pada akar tanaman pisang yang diberi perlakuan bakteri endofit (Gambar 1). Hal yang sama juga dilaporkan oleh Harish et al. (2008). Perlakuan kombinasi bakteri endofit dan Plant Growth Promotting Rhizobacteria pada bibit pisang mengimbas ketahanan tanaman pisang terhadap Banana Bunchy Top Virus dengan meningkatkan aktivitas peroksidase, polifenol oksidase, phenilalanin amonia liase, fenol, kitinase, dan $\beta-1,3$ glukanase.

Peningkatan aktivitas peroksidase dan polifenol oksidase juga terjadi pada tanaman kontrol (tanpa perlakuan bakteri endofit). Hal ini terjadi sebagai reaksi dari tanaman terhadap infeksi patogen ( $R$. solanacearum Phylotipe IV) dan pelukaan akar sebelum inokulasi patogen. Menurut Goodman et al. (1986), jaringan tanaman yang diinfeksi patogen menunjukkan perubahan pola metabolik, diantaranya adalah pengaktifan enzim peroksidase dan oksidasi fenol lainnya. Agrios (2005) juga menyatakan bahwa mikroorganisme patogen atau kerusakan mekanis dan kimia dapat merangsang tanaman untuk menghasilkan senyawa toksin terhadap patogen (fitoaleksin).

Peningkatan aktivitas peroksidase merupakan salah satu indikator pengimbasan ketahanan yang ditemukan pada semua perlakuan isolat bakteri endofit. Aktivitas peroksidase berperan penting dalam mekanisme penguatan dinding sel tanaman (lignifikasi) dan produksi senyawa-senyawa fenolik. Penguatan dinding sel tanaman dapat menghambat proses infeksi awal patogen karena patogen memerlukan nutrisi dari dalam sel tanaman. Selain itu, sel tanaman berperan sebagai tempat berlangsungnya mekanisme yang mengatur aktivitas respon pertahanan tanaman terhadap serangan patogen.

Perbandingan peningkatan aktivitas peroksidase pada akar tanaman sebelum inokulasi $R$. solanacearum Phylotipe IV dan 14 hari setelah inokulasi $R$. solanacearum Phylotipe IV lebih tinggi pada semua tanaman yang diberi perlakuan bakteri endofit dibandingkan dengan tanaman kontrol. Peningkatan aktivitas peroksidase tertinggi terjadi pada tanaman yang diberi perlakukan isolat bakteri endofit EAL15 yaitu 0,395 UEA/mg protein, diikuti oleh EKK10 (0,391 UEA/ mg protein), EKK20 (0,345 UEA/mg protein), EKK22 (0,097 UEA/mg protein) dan kontrol $(0,066 \mathrm{UEA} / \mathrm{mg}$ protein).

Menurut Silva et al. (2004), tingginya aktivitas peroksidase dapat menghambat proses infeksi patogen karena terjadinya lignifikasi dan pembentukan hidrogen peroksida yang menghambat patogen secara langsung atau pembentukan radikal bebas yang mempunyai efek anti mikroba. Peroksidase berperan sebagai katalis dalam polimerasi monolignols (alkohol p-caumaryl, coniferyl, dan sinapyl) yang membangun lignin (Vickery \& Brian, 1981; Vidhyasekaran, 2004). Infiltrasi lignin di dalam ruang mikrofibril dinding sel dapat meningkatkan kekuatan mekanik sel tanaman terhadap penetrasi patogen, meningkatkan ketahanan dinding sel tanaman terhadap degradasi oleh enzim-enzim patogen, dan membentuk impermeability bariers terhadap aliran nutrisi dan toksin (Huang, 2001; Strange, 2003).

Perbandingan peningkatan aktivitas polifenol oksidase pada akar tanaman sebelum inokulasi $R$. solanacearum Phylotipe IV dan 14 hari setelah inokulasi $R$. solanacearum Phylotipe IV lebih tinggi pada tanaman yang diberi perlakuan isolat bakteri endofit EAL15, EKK10, EKK20 dibandingkan dengan tanaman kontrol BDB, sedangkan tanaman yang diberi perlakuan isolat bakteri endofit EKK22 lebih rendah dibandingkan tanaman kontrol (Gambar 1). Peningkatan aktivitas 

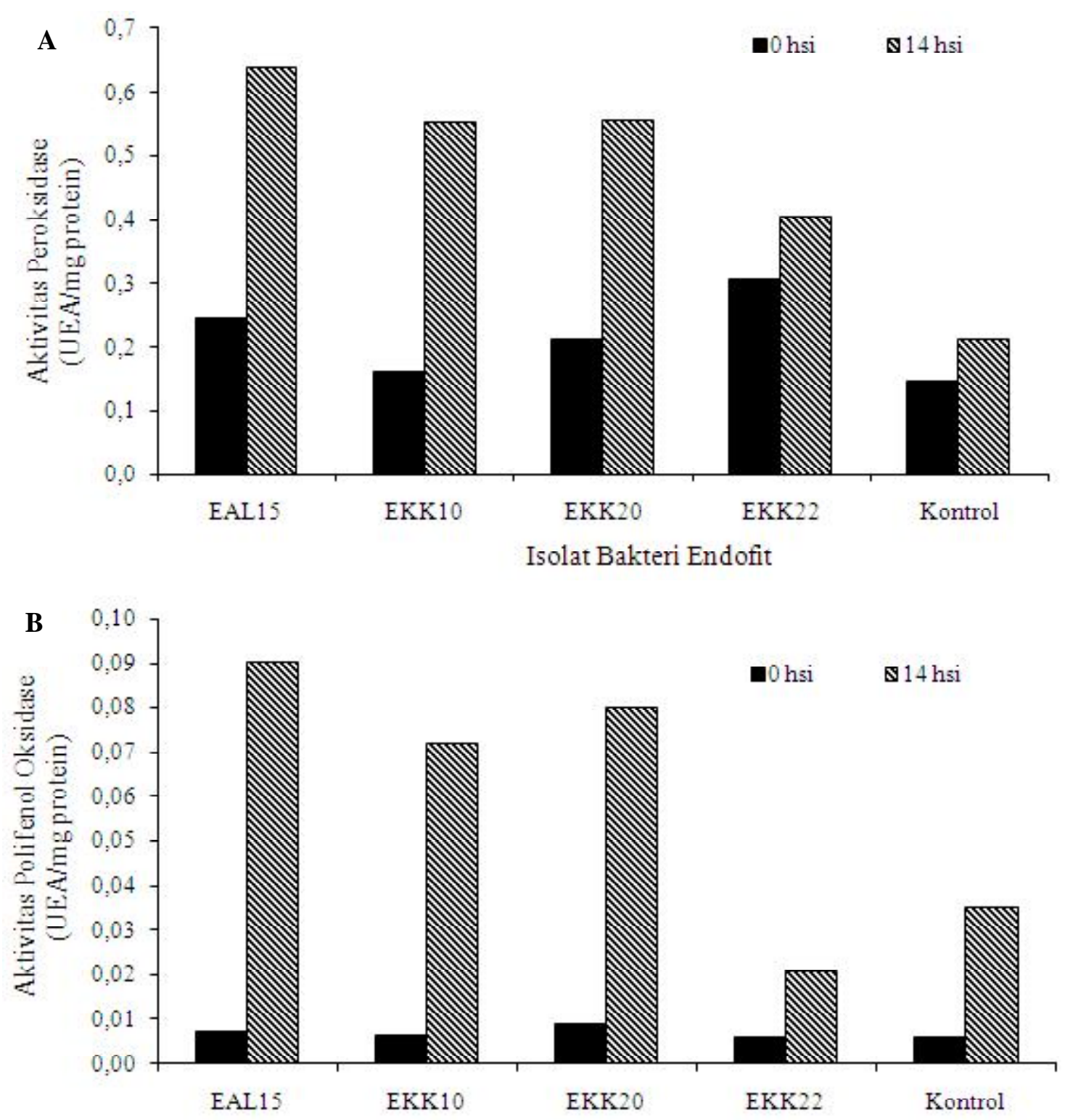

Isolat Bakteri Endofit

Gambar 1. Pengaruh isolat bakteri endofit EAL15, EKK10, EKK20 dan EKK22 terhadap aktivitas peroksidase (A) dan polifenol oksidase (B) pada akar tanaman pisang Cavendish sebelum inokulasi $R$. solanacearum Phylotipe IV (0 hsi) dan 14 hari setelah inokulasi R. solanacearum Phylotipe IV (14 hsi).

polifenol oksidase pada tanaman yang diberi perlakukan isolat bakteri endofit EAL15 adalah 0,083 UEA/mg protein, EKK10 (0,065 UEA/mg protein), EKK20 (0,071 $\mathrm{UEA} / \mathrm{mg}$ protein), EKK22 (0,015 UEA/mg protein) dan kontrol (0,029 UEA/mg protein).

Menurut Goodman et al. (1986), aktivitas polifenol oksidase dapat mengimbas reaksi hipersensitif dan secara bersamaan meningkatkan konsentrasi quinon yang bersifat cytotoxic. Sehubungan dengan ketahanan tanaman terhadap penyakit, aktivitas polifenol oksidase merupakan properti untuk mengoksidasi senyawa fenol menjadi quinon, yang lebih beracun terhadap mikroorganisme dibandingkan dengan senyawa fenol. Peningkatan aktivitas polifenol oksidase akan menghasilkan toksin dalam konsentrasi tinggi, sehingga meningkatkan ketahanan tanaman terhadap infeksi patogen (Agrios, 2005).

\section{Kandungan Asam Salisilat pada Akar Tanaman} Pisang. Kandungan asam salisilat pada akar tanaman pisang Cavendish dengan perlakuan isolat bakteri endofit EAL15, EKK10, EKK20 dan EKK22 pada 14 hari 
setelah diinokulasi dengan $R$. solanacearum Phylotipe IV dapat dilihat pada Gambar 2. Kandungan asam salisilat pada akar tanaman pisang dengan perlakuan isolat bakteri endofit EKK10 (205,23 ppm/g akar) dan EAL15 (187,45 ppm/g akar) lebih tinggi 25,56 ppm/g akar dan 7,78 ppm/g akar dibandingkan dengan tanaman kontrol (179,67 ppm/g akar). Tingginya kandungan asam salisilat pada tanaman dengan perlakuan isolat EKK10 dan EAL15 berhubungan dengan tingkat ketahanan tanaman terhadap infeksi $R$. solanacearum Phylotipe IV. Perlakuan isolat EKK10 dan EAL15 mampu menekan kejadian penyakit darah sebesar 70 dan $85 \%$ (Tabel 2). Silverman et al. (1995) menyatakan bahwa tingkat ketahanan tanaman ditentukan oleh ekspresi asam salisilat yang berkorelasi positif dengan kandungan asam salisilat.

Peningkatan kandungan asam salisilat pada tanaman yang diberi perlakuan bakteri endofit telah dilaporkan oleh penelitian lain. Kloepper \& Ryu (2006), melaporkan bahwa kolonisasi bakteri endofit Bacillus pumilus SE34 pada Arabidopsis memicu pengimbasan ketahanan sistemik terhadap Pseudomonas syringae pv. maculicola yang berhubungan dengan jalur asam salisilat. Forchetti et al. (2010) juga melaporkan bahwa perlakuan bakteri endofit Achromobacter xylosoxidans dan Bacillus pumilus meningkatkan pertumbuhan bibit bunga matahari pada kondisi stress air, memproduksi asam salisilat dan menghambat pertumbuhan cendawan patogen.
Asam salisilat mempunyai peranan penting dalam jalur sinyal yang memicu pengimbasan ketahanan sistemik dan berhubungan dengan akumulasi Pathogenesis-related protein (protein PR), seperti PR1 (Lyon, 2007). Menurut Heil \& Bostock (2002) berdasarkan beberapa literatur, asam salisilat berperan dalam jalur pengimbasan ketahanan sistemik yaitu pada tingkat elicitation dan signalling. Pada tingkat elicitation, asam salisilat disintesis sebagai respon terhadap kerusakan mekanik, nekrosis dan stres oksidatif, selanjutnya ditrasportasikan secara sistemik. Pada tingkat signalling, asam salisilat berperan sebagai pengatur jalur sinyal untuk ekspresi gen yang berhubungan dengan komponen dinding sel, fitoaleksin, protein PR, dan senyawa fenol.

Hasil analisis aktivitas enzim pertahanan tanaman (peroksidase dan polifenol oksidase) dan kandungan asam salisilat menunjukkan bahwa penekanan kejadian penyakit darah pada tanaman pisang oleh isolat bakteri endofit EAL15, EKK10, EKK20 dan EKK22 terjadi melalui mekanisme pengimbasan ketahanan tanaman. Bakteri endofit EAL15 dan EKK10 menunjukkan indikator pengimbasan ketahanan pada tanaman melalui peningkatan aktivitas peroksidase dan polifenol oksidase, serta peningkatan kandungan asam salisilat. Isolat bakteri endofit EKK20 menunjukkan indikator peningkatan aktivitas peroksidase dan polifenol oksidase, sedangkan EKK22 menunjukkan indikator pengimbasan ketahanan melalui peningkatan aktivitas peroksidase.

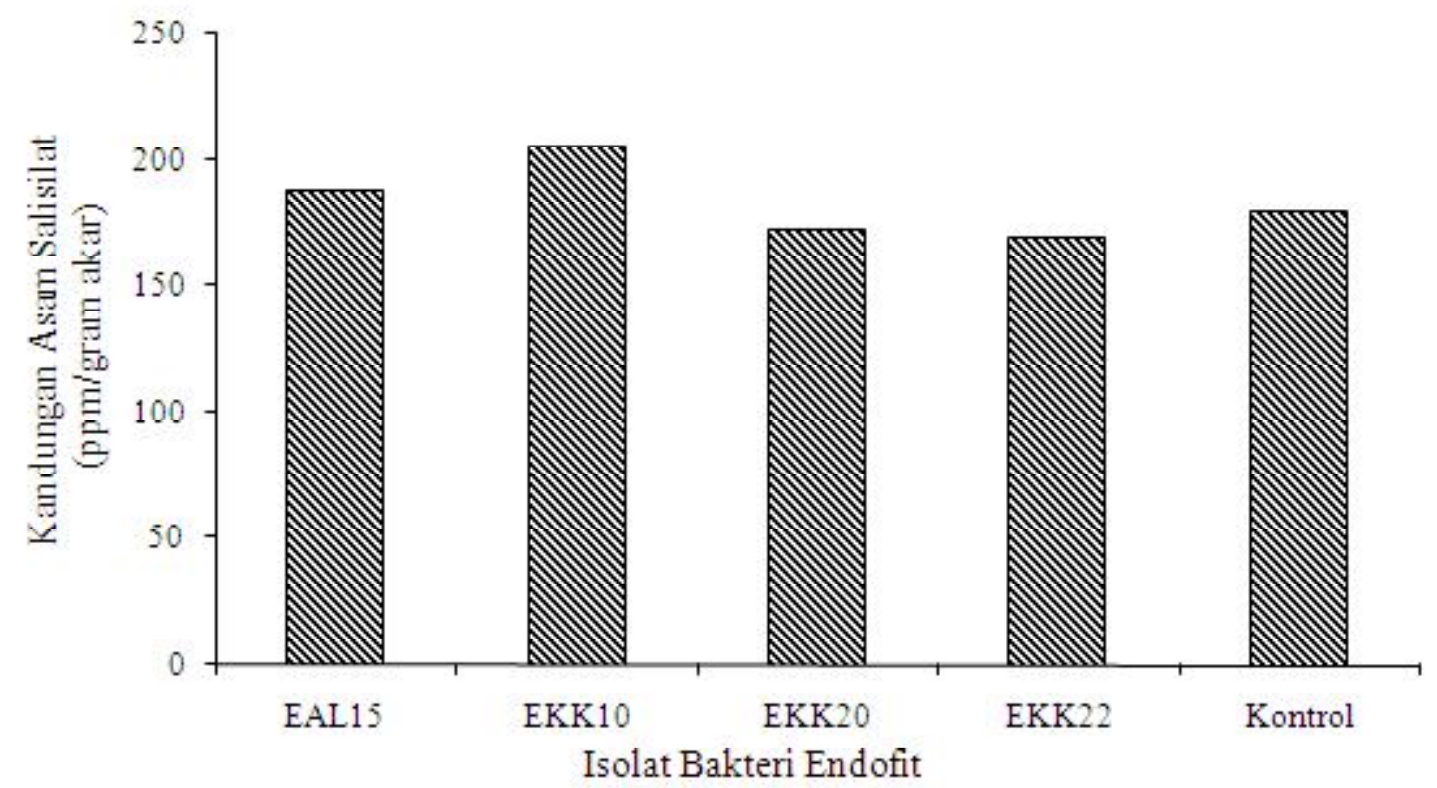

Gambar 2. Pengaruh bakteri endofit EAL15, EKK10, EKK20 dan EKK22 terhadap kandungan asam salisilat pada tanaman pisang Cavendish pada 14 hari setelah inokulasi $R$. solanacearum Phylotipe IV. 


\section{SIMPULAN}

Isolat bakteri endofit EAL15, EKK10, EKK20 dan EKK22 menunjukkan mekanisme pengimbasan ketahanan dalam mengendalikan penyakit darah pada tanaman pisang. Isolat EAL15 meningkatkan aktivitas peroksidase $(0,395 \mathrm{UEA} / \mathrm{mg}$ protein), polifenol oksidase $(0,083 \mathrm{UEA} / \mathrm{mg}$ protein), dan kandungan asam salisilat (7,78 ppm/g akar) pada tanaman pisang setelah inokulasi $R$. solanacearum Phylotipe IV. Isolat EKK10 meningkatkan aktivitas peroksidase $(0,391 \mathrm{UEA} / \mathrm{mg}$ protein), polifenol oksidase ( $0,065 \mathrm{UEA} / \mathrm{mg}$ protein), dan kandungan asam salisilat $(25,56 \mathrm{ppm} / \mathrm{g}$ akar $)$ pada tanaman pisang setelah inokulasi $R$. solanacearum Phylotipe IV. Isolat EKK20 meningkatkan aktivitas peroksidase $(0,345 \mathrm{UEA} / \mathrm{mg}$ protein) dan polifenol oksidase $(0,071 \mathrm{UEA} / \mathrm{mg}$ protein) pada tanaman pisang setelah inokulasi $R$. solanacearum Phylotipe IV. Isolat EKK22 meningkatkan aktivitas peroksidase $(0,097$ UEA/mg protein) pada tanaman pisang setelah inokulasi $R$. solanacearum Phylotipe IV.

\section{SANWACANA}

Terima kasih kepada DP2M DIKTI yang membantu pendanaan penelitian ini melalui program Hibah Bersaing DIKTI tahun 2009-2011 dan Dr. Ir. Supriadi, M.Sc (Balittro Bogor) atas informasi dan sarannya dalam penelitian pelaksanaan penelitian ini.

\section{DAFTAR PUSTAKA}

Agrios GN. 2005. Plant Pathology. 5th Edition. Academic Press, New York.

Forchetti G, Masciarelli O, Izaguirre MJ, Alemano S, Alvarez D, \& Abdala G. 2010. Endophytic bacteria improve seedling growth of sunflower under water stress, produce salicylic acid, and inhibit growth of pathogenic fungi. Curr. Microbiol. 61(6): 485-93.

Goodman RN, Kiraly Z, \& Wood KR.1986. The Biochemistry and Physiology of Plant Disease. University of Missouri Press, Columbia.

Hammerschmidt R. 1999. Induced disease resistance : how do induced plants stop pathogens? Physiol. Mol. Plant Pathol. 55(2): 77-84.
Harish S, Kavino M, Kumar N, Saravanakumar D, Soorianathasundaram K, \& Samiyappan R. 2008. Biohardening with plant growth promoting rhizosphere and endophytic bacteria induces systemic resistance against banana bunchy top virus. Appl. Soil Ecol. 39(2): 187-200.

Heil M \& Bostock RM. 2002. Induced systemic resistance (ISR) against pathogens in the context of induced plant defences. Ann. Bot. 89(5): 503512.

Huang JS. 2001. Plant Pathogenesis and Resistance : Biochemistry and Physiology of PlantMicrobe Interactions. Kluwer Academic Publishers, The Netherlands.

Kloepper JW \& Tuzun S. 1996. Induced systemic to diseases and increased plant growth-promoting rhizobacteria under field conditions. Phytopathol. 81: 1508-1516.

Kloepper JW \& Ryu C-M. 2006. Bacterial endophytes as elicitors of induced systemic resistance. In : Schulz B, Boyle C, \& Sieber TN (Eds.). Microbial Root Endophytic. pp.33-43. Springer Berlin Heidelberg.

Kuc J. 1987. Plant Immunization and its Applicability for Disease Control. In : Chet I. (Ed.). Innovative Approaches to Plant Disease Control. pp. 225272. John Wiley and Sons, New York.

Kuc J. 1995. Phytoalexins, stress metabolism, and disease resistance in plant. Annu. Rev. Phytopathol. 33: 275-297.

Kumar AR, Kumar N, Poornima K, \& Soorianathasundaram K. 2008. Screening of invitro derived mutants of banana against nematodes using biochemical parameters. Am. Eur. J. Sus. Agri. 2(3): 271-278.

Lamb C \& Dixon RA. 1997. The oxidative burst in plant disease resistance. Annu. Rev. Plant Physiol. Plant Mol. Biol. 48: 251-275.

Lelliot RA \& Stead DA. 1987. Methods for The Diagnosis of Bacterial Disease of Plant. Oxford : Blackwell Scientific Publication.

Lyon G. 2007. Agents that can elicit induced resistance. In: Walters D, Newton A, \& Lyon G. (Eds.). Induced Resistance for Plant Defence: Sustainable Approach to Crop Protection. pp.9-30. Blackwell Publishing Ltd, Oxford. 
Marwan H, Sinaga MS, Giyanto, \& Nawangsih AA. 2011. Isolasi dan seleksi bakteri endofit untuk pengendalian penyakit darah pada tanaman pisang . J. HPT Tropika 11(2): 112-119.

Press CM, Loper JE, \& Kloepper JW. 2001. Role of iron in rhizobacteria-mediated induced systemic resistance of cucumber. Phytopathology 91(6): 593-598.

Rasmussen JB, Hammerschmidt R, Zook MN. 1991. Systemic induction of salicylic-acid accumulation in cucumber after inoculation with Pseudomonas syringae pv. syringae. Plant Physiol. 97(4): 1342-1347.

Silva HSA, Romeiro RS, Macagnan D, Halfeld-vieira BA, Pereira MCB, \& Mounteer A. 2004. Rhizobacterial induction of systemic resistance in tomato plants: non-specific protection and increase in enzyme activities. Biol. Control 29(2): 288-295.

Silverman P, Seskar M, Kanter D, Schweizer P, Metraux J. 1995. Salicylic acid in rice (biosynthesis, conjugation, and possible role). Plant Physiol. 108: 633-639.

Strange RN. 2003. Introduction to Plant Pathology. John Wiley \& Sons Ltd., England. van Loon LC. 1997. Induced resistance in plants and role of pathogenesis-related proteins. Eur. J. Plant Pathol. 103(9): 753-765.

van Loon LC, Bakker PAHM, \& Pieterse CMJ. 1998. Systemic resistance induced by rhizosphere bacteria. Annu. Rev. Phytopathol. 36: 453-483.

Vickery ML \& Brian V. 1981. Secondary Plant Metabolism. The MacMillan Press Ltd., London.

Vidhyasekaran P. 2004. Concise Enclyclopedia of Plant Pathology. Food Product Press and Howard Reference Press, London.

Wei G, Kloepper JW, \& Tuzun S. 1991. Induction of systemic resistance of cucumber to Colletotrichum orbiculare by select strains of plant growth-promoting rhizobacteria. Phytopathology 81(12): 1508-1512.

Wei G, Kloepper JW, \& Tuzun S. 1996. Induced systemic resistance to cucumber diseases and increased plant growth by plant growth-promoting rhizobacteria under field conditions. Phytopathology 86(2): 221-224. 